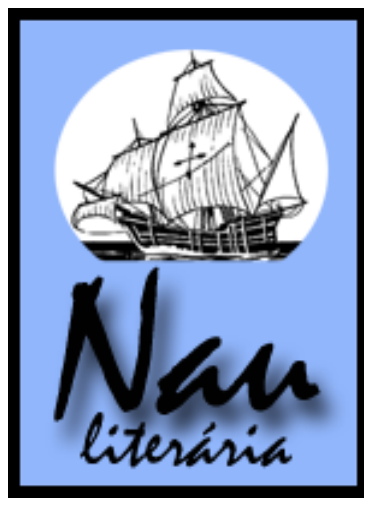

Nau Literária: crítica e teoria de literaturas • seer.ufrgs.br/NauLiteraria

ISSN 1981-4526 • PPG-LET-UFRGS • Porto Alegre • Vol. 10 N. 02 • jul/dez 2014 Dossiê:

Migração, exílio e identidade

\title{
Poema sujo: da memória individual à memória coletiva
}

\section{Pablo Ramos Silveira*}

\begin{abstract}
Resumo: Este artigo tem por objetivo analisar as possíveis relações entre a memória individual e a memória coletiva, a partir da leitura da obra Poema sujo, de Ferreira Gullar. Ao longo do trabalho, será estudado como o eu poético pode representar um acontecimento vivenciado por toda uma sociedade, num determinado período histórico. Para isso, surge a necessidade de avaliar os elementos textuais que permitam a realização da análise, por exemplo, as referências espaciais e as marcas de temporalidade presentes no texto.
\end{abstract}

Palavras-chave: Poesia; Memória individual; Memória coletiva.

\begin{abstract}
Resumen: Este artículo tiene por objetivo analizar las posibles relaciones entre la memoria individual y la memoria colectiva, a partir de la lectura de la obra Poema sucio, de Ferreira Gullar. A lo largo del trabajo, se estudiará cómo el yo poético puede representar un acontecimiento vivido por toda una sociedad, en un determinado periodo histórico. Para eso, surge la necesidad de evaluar los elementos textuales que permitan la realización del análisis, por ejemplo, las referencias espaciales y las marcas de temporalidad presentes en el texto.
\end{abstract}

Palabras clave: Poesía; Memoria individual; Memoria colectiva.

No Poema sujo, Ferreira Gullar consegue atingir um elevado grau de poeticidade, o que o situa entre os grandes poetas brasileiros do século XX. Sua experiência pessoal, associada ao contexto sócio-histórico das décadas de 1960 e 1970, foi fundamental para a tessitura de um dos poemas mais originais da literatura brasileira. Poucos autores fizeram de suas vivências objeto de tão elevada arte, não caindo no ataque fácil ao opressor que, muitas vezes, transparece um conteúdo débil e panfletário, incapaz de transcender os limites da linguagem comum. Felizmente, Gullar ultrapassa as fronteiras do revanchismo pernicioso, já que sua poesia ruma em direção ao compromisso com a palavra: matéria-prima em que o poeta sublima a linguagem.

O Poema sujo é uma obra, por excelência, mnemônica, uma vez que o poeta relata a necessidade de transformar sua massa existencial em poesia, devido ao estado emocional em que se encontrava naquele momento. Por isso, $\mathrm{FG}^{1}$ resolve emergir do passado todas as lembranças possíveis, materializadas pela palavra, presentificando os fatos transcorridos, de acordo com o excerto abaixo:

\footnotetext{
* Licenciado em Letras Português/Espanhol e suas Respectivas Literaturas pela Universidade Federal do Pampa (Unipampa). Participa do grupo de pesquisa GEBAP - Grupo de Estudos Bakhtinianos do Pampa desde o segundo semestre de 2011. Atualmente, é aluno de mestrado em Literatura Comparada do PPG da UFRGS.

${ }^{1}$ Abreviatura de Ferreira Gullar, usada para se referir ao poeta.
} 
À parte qualquer juízo de valor, tinha noção de que, ao escrevê-lo, vivera uma experiência poética única, por sua longa duração e pelo estado especial em que o fizera, de extraordinária liberdade interior, que tornava atuais, presentes, todas as palavras, todos os cheiros, os sons, os afagos, as sensações experimentadas e as vozes ouvidas e lidas, da infância, da família, dos amores, dos poetas. (GULLAR, 2013, p.12)

Desse modo, a memória individual é fio condutor para a construção da obra, visto que as sensações vivenciadas no passado pertencem a um dado período da história, que abrange a vida de toda uma coletividade. Essa relação entre memória pessoal e coletiva permeia o texto poético gullariano, que complexifica a tensão do eu lírico com a sociedade da época, mesmo que essa voz esteja apartada de seu ambiente de enunciação, isto é, a cidade de São Luís. Portanto, o Poema sujo nada mais é do que a evocação do poeta à sua cidade natal, situando espacial e temporalmente a existência de um homem marcada sob o signo da poesia.

No início do Poema sujo, já que a obra é dividida em nove partes, o eu lírico procura realizar uma tentativa de rememoração do passado. Nesse ponto, surge a dificuldade de expressar, em linguagem poética, a experiência vivida, que permanece presa a um estágio préverbal, sendo preciso um grande esforço para trazer à tona toda essa realidade esquecida, que contém o cordão umbilical para a desenvoltura do poema, segundo os versos a seguir:

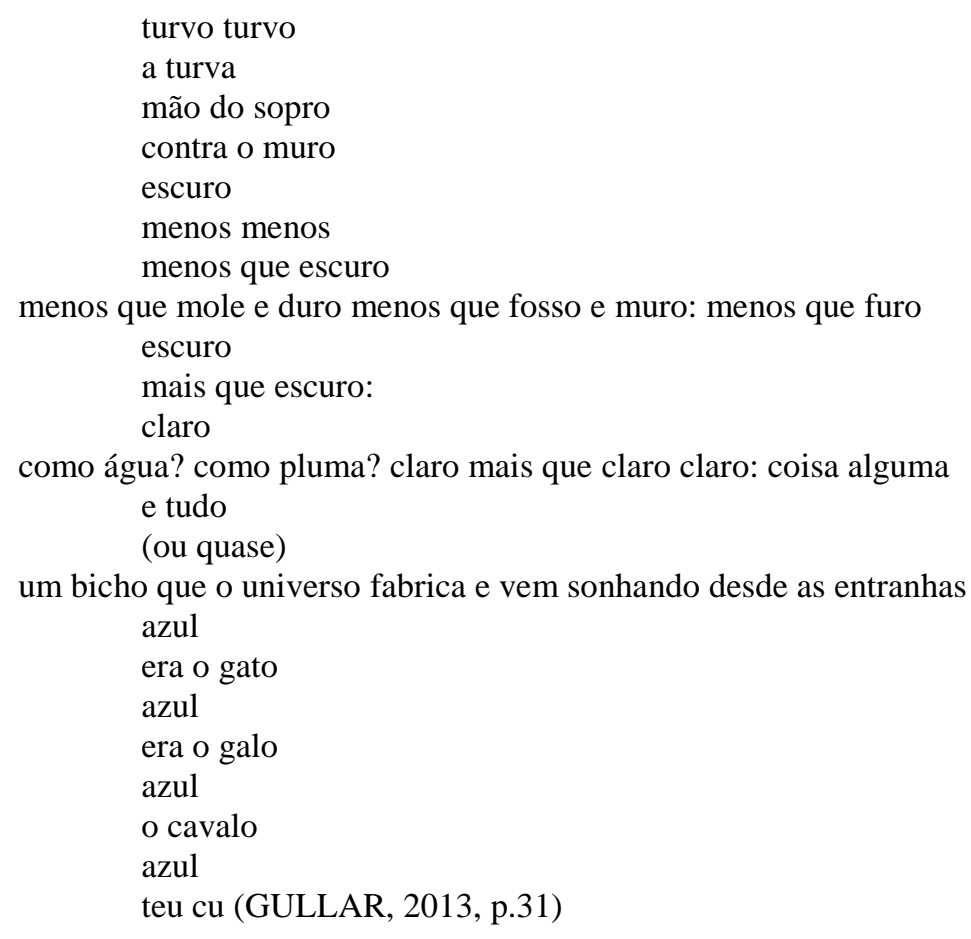

Consequentemente, a rememoração do passado realizada pelo eu lírico exige um forte empenho em recuperar os fatos esquecidos na memória. Isso mostra que o ato de rememorar se diferencia da simples evocação, já que pode ser considerado um ato voluntário, que demanda maiores esforços. Ademais, a rememoração (ou a reevocação) permite ao eu lírico escavar as 
profundezas da memória, a fim de buscar o material necessário para a tessitura do seu corpus poético, que tende a revelar-se na força imagética contida nos versos. Para isso, vale a pena recorrer ao conceito de rememoração, proposto pelo teórico Paolo Rossi:

Voltar a lembrar implica um esforço deliberado da mente; é uma espécie de escavação ou de busca voluntária entre os conteúdos da alma: quem rememora "fixa por ilação o que antes viu, ouviu ou experimentou e isso, em substância, é uma espécie de pesquisa; diz respeito somente a quem possui capacidade deliberativa, porque deliberar também é uma forma de ilação" [...] (ROSSI, 2010, p. 16)

De certo modo, torna-se imprescindível considerar o Poema sujo uma obra em que perpassam marcas autobiográficas, ainda que se saiba da diferença existente entre o eu pessoal e eu lírico. Sabe-se que o eu lírico é o resultado da expressão imaginativa do poeta, o que legitima o processo de criação literário. Muitas vezes, confunde-se o indivíduo (a figura autoral) com o eu criador, principalmente quando se trata de poesia, uma vez que alguns leitores tendem a atribuir ao poeta as experiências descritas no poema, algo que pode levar a uma banalização da lírica enquanto produto literário de qualidade. Embora se tenha conhecimento dessa distinção, não se pode rejeitar a relação existente entre o eu individual e o eu lírico expresso no Poema Sujo, pois o próprio FG afirmou que sua mais relevante obra seria uma espécie de "testemunho final": "Decidi, então, escrever um poema que fosse o meu testemunho final, antes que me calassem para sempre" (GULLAR, 2013, p. 9).

A iniciação sexual do eu lírico é retratada, de modo que o sexo ilustra a imagem de uma memória corpóreo-sensorial, capaz de aflorar a qualquer instante, sobretudo, quando o passado se transforma em uma realidade presente. Ademais, há uma espécie de equilíbrio temático, associada ao voyeurismo latente no texto, ou seja, "os cheiros de flor" são postos ao lado da "bosta de porco", o que demonstra a sublimação do baixo tema; daquilo que aparentemente não merece ser conteúdo da poesia. Assim, FG demonstra que a poesia alcança todas as instâncias da linguagem, jamais desprezando aquilo que é considerado relativamente baixo ou sujo, uma vez que cabe ao poeta ter a capacidade alquímica de transformar qualquer matéria poética no mais reluzente ouro:

$$
\begin{aligned}
& \text { tua gengiva igual a tua bocetinha que parecia sorrir entre as } \\
& \text { folhas de banana entre os cheiros de flor e bosta de porco aberta } \\
& \text { como uma boca do corpo (não como a tua boca de palavras) } \\
& \text { como uma entrada para } \\
& \text { eu não sabia tu } \\
& \text { não sabias } \\
& \text { fazer girar a vida } \\
& \text { com seu montão de estrelas de oceano } \\
& \text { entrando-nos em ti (GULLAR, 2013, p. 32) }
\end{aligned}
$$

No que se refere ao exílio do poeta, a clandestinidade é tratada por meio da relação entre 
espaço físico e memória individual, visto que a ocorrência desse acontecimento também diz respeito a uma época vivenciada por milhares de indivíduos durante o período da ditadura militar. No Brasil, o golpe de 1964 foi responsável pelo desaparecimento de inúmeras pessoas que lutavam contra os excessos provocados pelo novo regime, algo semelhante também ocorreu em países da América do Sul, como Uruguai, Argentina e Chile.

Dessa forma, FG consegue expressar, a partir de sua voz poética, um fato histórico vivenciado pela sociedade brasileira, principalmente, nas décadas de 1960 e 1970, quando o regime militar estava no auge do poder. O poeta maranhense utiliza seus versos para atacar ou denunciar as atrocidades praticadas pelo governo da época, além de retroagir na história e firmar um engajamento com a palavra, sem cair nas facilidades de um discurso demagógico, que colocaria em risco a qualidade literária de sua produção:

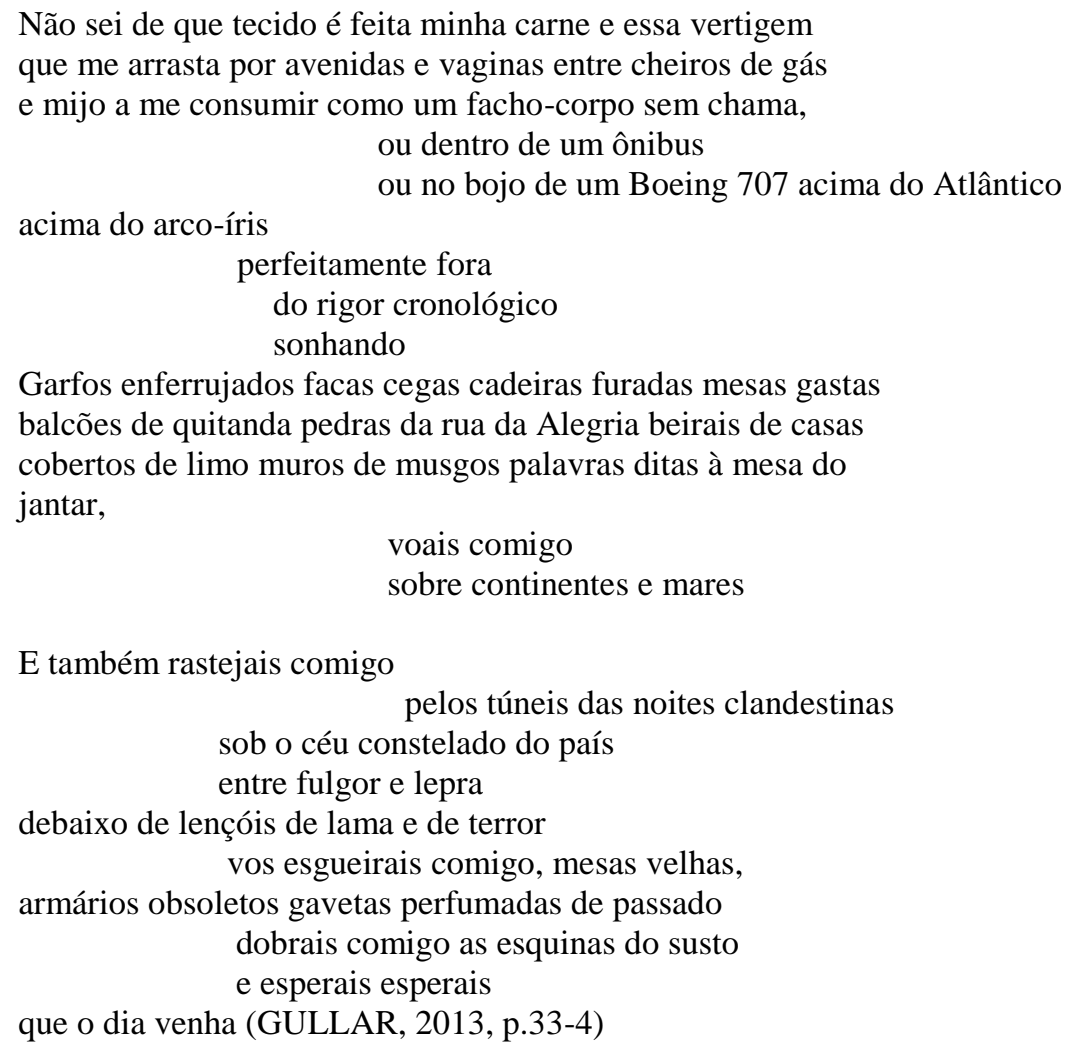

Como se pôde denotar nos versos anteriores, a passagem do tempo ocorre pela deterioração dos objetos que caracterizavam o cotidiano do poeta, além do vínculo de afeto estabelecido com o ambiente familiar. "Garfos enferrujados", "cadeiras furadas", "mesas gastas", "balcões de quitanda", "beirais de casas/cobertos de limo", "muros de musgos" e "palavras ditas à mesa do jantar" são elementos constitutivos de eventos mnemônicos, os quais retratam a vida desse eu lírico em pleno diálogo com o passado, na tentativa de revivificar as experiências de um cotidiano familiar perdido no tempo, já que o presente se revela um âmbito 
hostil, impregnado extremamente de insegurança.

Nesse instante, surge outra vez a presença da memória coletiva, quando o eu poético recupera o contexto histórico da Segunda Guerra Mundial (1939-1945), vivenciado pelos moradores de São Luís do Maranhão. Além disso, o menino de outrora está entrelaçado à sua realidade e não se aparta do poeta enquanto adulto:

Era a vida a explodir por todas as fendas da cidade

sob as sombras da guerra:

a gestapo a wehrmacht a raf a feb a blitzkrieg catalinas torpedeamentos a quinta-coluna os fascistas os nazistas os comunistas o repórter esso a discussão na quitanda o querosene o sabão de andiroba o mercado negro o racionamento o blackout as montanhas de metais velhos o italiano assassinado na praça João Lisboa o cheiro de pólvora os canhões alemães troando nas noites de tempestade por cima da nossa casa. Stalingrado resiste.

Por meu pai que contrabandeava cigarros, por meu primo que passava rifa, pelo tio que roubava estanho à Estrada de Ferro, por seu Neco que fazia charutos ordinários, pelo sargento Gonzaga que tomava tiquira com mel de abelha e trepava com a janela aberta, pelo meu carneiro manso por minha cidade azul pelo Brasil salve salve,

Stalingrado resiste. (GULLAR, 2013, p.35-6)

Vale ressaltar, ainda, uma possível relação intertextual, mnemônica que o texto gullariano mantém com os poemas Carta a Stalingrado e Canto a Stalingrado, de Carlos Drummond de Andrade e de Pablo Neruda, respectivamente, que se referem à histórica Batalha de Stalingrado, na qual as tropas soviéticas lutavam contra o avanço do exército nazista, tornando-se símbolo de luta e de resistência em posição ao regime opressor de Hitler. Desse modo, FG dialoga com dois importantes nomes da lírica do continente americano, o que mostra a complexidade de seu poema, por meio da diversidade de vozes que circulam em seu interior. Mesmo assim, Gullar retoma a tradição sem realizar maiores considerações a respeito do assunto, apenas se irmanando ao clamor dos referidos poetas, já que não aprofunda seu olhar sobre os efeitos causados pela Segunda Guerra.

Cabe agregar que a poesia possui uma forte ligação com a história, visto que o poeta, ao escrever o seu poema, consagra, por meio da palavra, a sociedade de sua época. No entanto, o poema não se limita aos cercos da história, pois qualquer leitor, independentemente do período histórico em que viva, atribuirá novos significados ao texto, o que não quer dizer que a história não seja fundamental para dar sentido a sua existência, como assegura o poeta e ensaísta mexicano Octavio Paz:

O poema, ser de palavras, vai mais além das palavras e a história não esgota o sentido do poema; mas o poema não teria sentido — e nem sequer existência — sem a história, sem a comunidade que o alimenta e à qual alimenta (PAZ, 2012, p.52).

A grande dificuldade em tornar coletiva a memória individual resulta da passagem de 
um eu para um nós, capaz de expressar os anseios e as experiências de uma coletividade. Para que isso aconteça, o poeta precisa ter consciência dessa necessidade, que acarreta em assumir a condição do outro a partir da sua condição, tarefa esta que não é fácil, conforme as palavras de Paul Ricoeur: "A consciência transcendental de fluxo designa então a si mesma como a de um eu sozinho, e a dificuldade consistirá em passar do ego solitário a um outrem capaz de se tornar, por sua vez, um nós” (RICOEUR, 2007, p. 124). Assim, a memória passa de individual à coletiva, sendo o poeta o grande mediador desse processo, no instante em que o eu lírico se transforma em um nós social.

Entretanto, o filósofo alemão Theodor W. Adorno especifica que toda obra de arte não se resume a mera expressão de sentimentos e experiências individuais, mas está relacionada diretamente com o meio social, a partir do momento em que essa comunidade se veja representada no poema. Dessa forma, poesia e sociedade são duas substâncias inseparáveis, sendo desnecessária a transformação de um $e u$ para um nós poético, como sugere Ricoeur; ao contrário, todo poema já é a expressão de uma emoção coletiva, desde que faça sentido e tenha um propósito estético:

\begin{abstract}
A relação com o social não nos deve afastar de obra de arte, mas, ao contrário, inserir-nos mais profundamente nela. Pois bem: a mais simples reflexão basta para mostrar que este aprofundamento deve ser esperado. Pois o conteúdo de um poema não é apenas a expressão de emoções e experiências individuais. Mas estas não chegam nunca ser artísticas a menos que consigam participação do geral por meio, precisamente, da especificação da essência de sua forma estética. (ADORNO, 1979, p. 343)
\end{abstract}

Outro ponto a destacar diz respeito à espacialidade, uma vez que o corpo é visto como um objeto que ocupa lugar no espaço. Com isso, a materialidade corporal é tomada como ponto de referência; é a partir dela que se configura tudo aquilo que está ao redor do poeta, ou seja, o eu lírico encontra-se no centro do universo, possuindo a percepção sobre si mesmo, segundo afirma o filósofo francês Henri Bergson: "Meu corpo é o que se desenha no centro das percepções; minha pessoa é o ser ao qual se devem relacionar tais ações” (BERGSON, 1990, p. 34). Por fim, a percepção sobre o próprio corpo não deixa de ser a porta de entrada para o mundo, problematizada na relação mundo/sujeito, em que o eu lírico vê a si como "massa de hidrogênio e hélio/que se desintegra e reintegra/sem se saber pra quê":

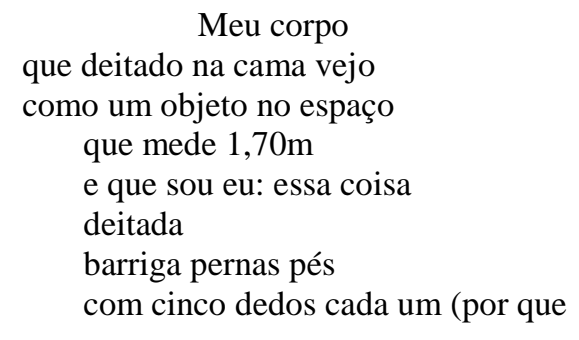


não seis?)

joelhos e tornozelos

para mover-se

sentar-se

levantar-se

meu corpo de $1,70 \mathrm{~m}$ que é meu tamanho no mundo

meu corpo feito de água

e cinza

que me faz olhar Andrômeda, Sírius, Mercúrio

e me sentir misturado

a toda essa massa de hidrogênio e hélio

que se desintegra e reintegra

sem se saber pra quê (GULLAR, 2013, p.38-9)

O começo da segunda parte do poema contrapõe a primeira. Ou melhor, o "turvo" — a memória individual em resistência — acaba sendo vencido pela clareza que o poeta possui tanto da consciência quanto da linguagem poética. Por conseguinte, o eu lírico parece ter compreensão e domínio sobre as experiências vividas, quando um "relâmpago clareia os continentes passados" e permite ao leitor viajar pelos túneis da memória, em que se podem ouvir "vozes perdidas na lama", na solidão de "domingos vazios":

\begin{tabular}{ll}
\multicolumn{2}{c}{$\begin{array}{c}\text { claro claro } \\
\text { mais que claro }\end{array}$} \\
\multicolumn{1}{c}{ raro } \\
o relâmpago clareia os continentes passados: & noite e jasmim \\
& junto à casa \\
vozes perdidas na lama & \\
domingos vazios (GULLAR, 2013, p. 42) &
\end{tabular}

É importante observar que há uma variedade de tempos coexistentes no interior do poema, o que resulta na fragmentação da memória, algo tão presente na formação do sujeito pós-moderno. Isso prova que a ação do tempo nunca é única, homogênea, uma vez que o ser humano demora a perceber os movimentos céleres do tempo, proporcionando a segmentação, por exemplo, de uma manhã ou de uma tarde. Além disso, o tempo se relaciona diretamente com o espaço físico, que se torna o termômetro dessa passagem no instante em que a tarde avança sobre o corpo e a vida da cidade:

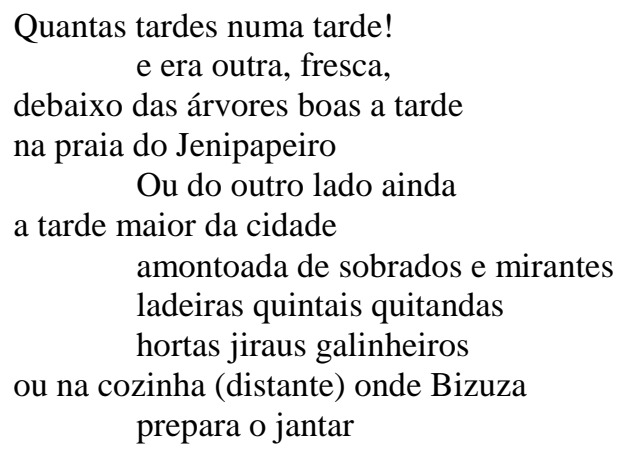




$$
\begin{aligned}
& \text { ah quantas só numa não canta } \\
& \text { tarde geral que cobre de nuvens a cidade } \\
& \text { tecendo no alto e conosco } \\
& \text { a história branca } \\
& \text { da vida qualquer (GULLAR, 2013, p.45) }
\end{aligned}
$$

Um aspecto interessante observado na obra de Gullar diz respeito ao eu lírico situar-se espacial e temporalmente, a partir da menção do lugar e do horário, como uma forma de o leitor acompanhar o itinerário realizado pelo poeta durante os dias passados no exílio, a fim de reviver essa experiência poética. Esta localização no tempo e no espaço proporciona um reconhecimento daquilo que permanece como memória individual, sem dissociar-se do período histórico, visto que Buenos Aires se converte no locus de enunciação poético, do qual se extraem os fatos necessários para tecer um cenário convidativo à rememoração:

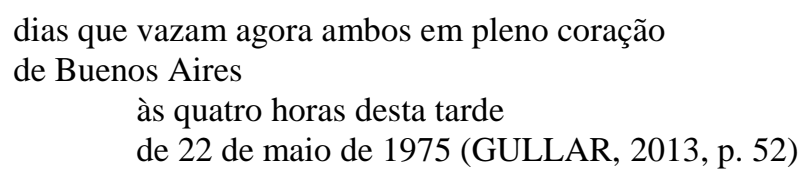

Dessa maneira, a datação permite a localização no tempo, bem como se torna um facilitador para a rememoração dos fatos, uma vez que a memória está vinculada intrinsecamente à passagem do tempo, isto é, sem memória, não há o tempo. Por isso, a inscrição da data no poema demonstra a qualidade reflexiva desse eu lírico, que não apenas descreve sua ação poética, mas se encontra consubstanciado com a memória e o tempo, frutos do empenho que se tem para transmutar essa viagem lírica num testemunho digno de reconhecimento e de potencial poético. Assim, o esforço mnemônico em registrar as experiências vividas pela datação dos fatos, sempre haverá de suscitar algumas interrogações, como sugere Paul Ricoeur:

A data, como lugar no tempo, parece assim contribuir para a primeira polarização dos fenômenos mnemônicos divididos entre hábito e memória propriamente dita. Ela também é constitutiva da fase reflexiva ou, como dizem, declarativa da recordação; esforço de memória é, em grande parte, esforço de datação: quando? há quanto tempo? quanto durou? (RICOEUR, 2010, p. 58)

Com relação à memória coletiva, FG tece uma crítica à história brasileira, quando se trata da representação do índio no imaginário popular. Sabe-se que o processo de colonização foi responsável pela morte de milhares de indígenas, provocando uma verdadeira hecatombe em solos recém-descobertos. Por conseguinte, o autor maranhense resgata o período histórico, já que a cidade de São Luís foi ocupada pelos franceses no final do século XVI, o que culminou na sua fundação, em 1612. O retrato da época, desenhado pelos versos de Gullar, revela uma São Luís que se imiscui com o presente, com seu cheiro, que “apodrece o Anil/ao leste”, e com 
sua miséria de espírito, sendo que homens se tornam escravos de outros, iguais em suas condições humanas; porém, desiguais pela truculência econômica e social que assola a população. Em resumo, o passado e o presente se misturam "quase diariamente no porto" da cidade, que retém os sinais de um tempo em que o homem era medido pela etnia à qual pertencia. Ou melhor, será a representação do índio apenas uma tela de fundo para expressar a vida de um passado que se faz, ainda, presente? A resposta está na interpretação de cada um dos leitores; daquilo que se pode absorver dos versos a seguir:

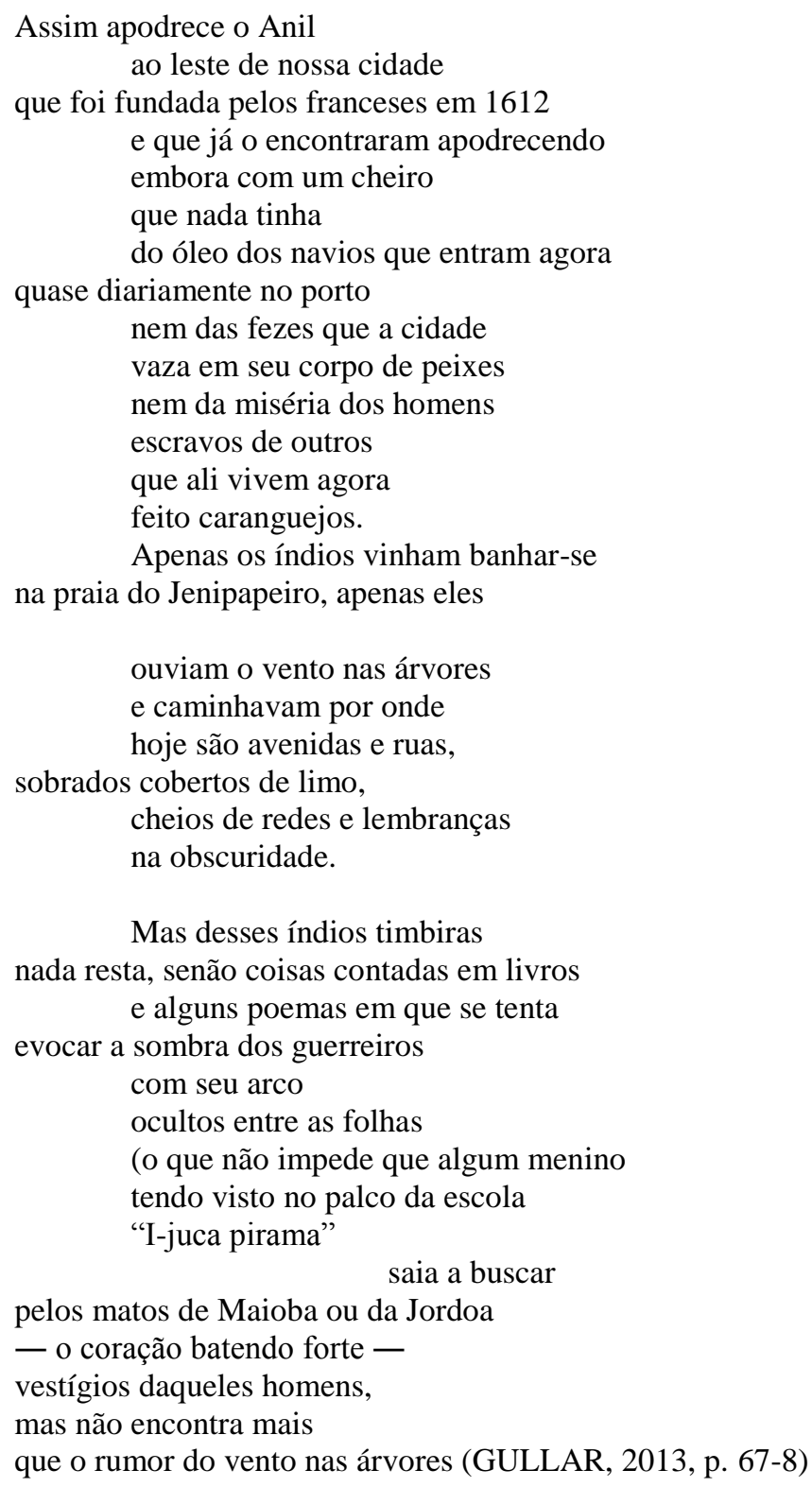

A imagem do índio só permanece viva por meio da literatura. Não seria pouco provável que FG estivesse assumindo um posicionamento crítico à forma como é abordada a figura indígena nas páginas das obras literárias. É confiável a sagração do índio como o valoroso guerreiro das matas, segundo a mitologia criada à sua sombra, principalmente, pelos escritores 
românticos? Infelizmente, a força do índio tende a desaparecer ante os olhos da história. Com isso, o poeta parece observar, com atenção, o espelho construído em torno do mito, no qual o índio reflete o braço forte e a beleza perfeita, sendo os filhos promissores de uma terra tropical chamada Brasil. Por fim, Gullar busca romper com a efígie romantizada do índio, embora essa idealização ainda possa ser observada na memória literária do país, como nos romances de José de Alencar e nos poemas de Gonçalves Dias (especialmente, em I-juca pirama).

A memória social de São Luís é contada por meio de seus personagens, por exemplo, as três filhas de "seu Cunha", o barbeiro, que representam a sociedade patriarcal da época, em que a figura feminina não passava de um ser assexuado, totalmente desprovido de vida sexual, além de zelar pelos "bons costumes" e pelo nome da família. Camélia, a que "caiu na vida", é revelação de uma conduta em pleno estado de ebulição, já que a maioria das mulheres não tinha o direito de escolher os rumos de sua existência, ficando presas ao pseudomoralismo burguês que dita/va as regras sociais, na tentativa de manter a hegemonia da classe dominante. E a filha mais velha, "a mais sonsa", que ia tomar injeção de Eucaliptina todo o santo dia?! O que dizer? Diante dessa situação, observa-se uma sociedade arraigada a valores arcaicos, que contrasta com o puritanismo religioso da terceira filha, que "ficou séria", abandonando a vida pregressa de descaminhos; agora, ela "virou filha de Maria":

\author{
Camélia caiu na vida \\ porque ainda não existia a pílula \\ Pagou caro aquele amor \\ feito com dificuldade \\ detrás do jirau de roupas \\ em pé junto à cerca \\ enquanto a família dormia \\ (o mesmo gosto de hortelã \\ das pastilhas de aniversário) \\ Seu pai, seu Cunha, o barbeiro, \\ quase morre de vergonha, \\ ele que fazia a barba \\ de todos os homens da rua \\ (e o curió na gaiola, \\ nem-seu-souza). \\ Por que vai um homem ter filhas, \\ meu Deus? E ele tinha três. \\ A mais velha, que era mais sonsa, \\ foi ao Josias tomar \\ uma injeção de Eucaliptina \\ e o enfermeiro aconselhou: \\ "Dói muito. É melhor num lugar \\ que tenha mais carne." \\ E desde esse santo dia \\ era injeção toda tarde. \\ (e o curió, \\ nem-seu-souza) \\ A terceira ficou séria \\ e virou filha de Maria
}


(e o curió, nem-seu-souza) (GULLAR, 2013, p. 73)

A ironia do eu lírico é externada por meio da reação do curió, que está "nem-seu-souza", frente ao escândalo moral provocado pelas filhas do barbeiro. Nesse ponto, o autor do Poema sujo investe numa crítica à memória social desse tempo, ainda que fosse um refúgio perante a solidão e a iminência da morte no coração do exílio. Isso não deixa de ser uma resposta ao passado, que sempre merece um olhar aprofundado, meditativo, capaz de gerar a reflexão de uma sociedade anestesiada pela inércia de preceitos e conjurações morais, de acordo com a tradição dos homens. Assim, nada melhor que a sensibilidade poética para escavar os túneis sombrios da memória de um povo, não com o intuito de colocar história no banco dos réus, decretando a sua condenação definitiva; mas devido à premência do conhecimento histórico que tão bem proporciona os textos literários.

Na sua relação com a cidade de São Luís, FG demonstra grande afeto pelo lugar em que nasceu. Esse sentimento telúrico, o qual suscita a emersão de tempos remotos, é oriundo do "cheiro da terra" e do "cheiro do mato verde", que invade o corpo do poeta e produz a sensação de retorno ao passado, de modo que a memória do indivíduo permanece entrelaçada ao espaço de origem:

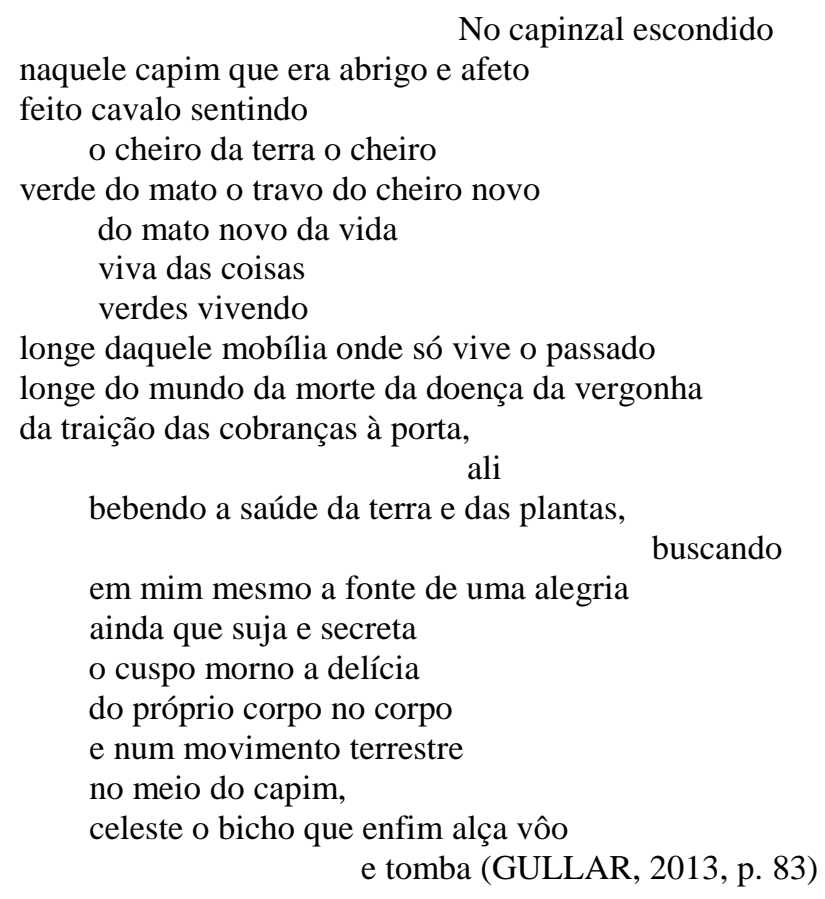

A partir dos versos citados anteriormente, pode-se inferir que o princípio da afecção está na percepção daquilo que o corpo humano absorve da exterioridade, mesclando-se com o seu conteúdo interior, o que resulta na redescoberta de uma pureza imagética, segundo atesta Bergson: "A afecção é portanto o que misturamos, do interior de nosso corpo, à imagem dos 
corpos exteriores; é aquilo que devemos extrair inicialmente da percepção para reencontrar a pureza da imagem" (BERGSON, 1990, p. 43).

$\mathrm{Na}$ parte final do poema, percebe-se nitidamente a relação da espacialidade com a memória individual, quando o eu lírico equaciona esse estreitamento entre o homem e a sua cidade, por meio de uma "fórmula poética", muito próxima às utilizadas pelo poeta pernambucano João Cabral de Melo Neto, em que condensa pensamento e objetividade, engendrando, assim, um elo de encaixe entre os versos, como se fosse um verdadeiro problema matemático:

\author{
O homem está na cidade \\ como uma coisa está em outra \\ e a cidade está no homem \\ que está em outra cidade (GULLAR, 2013, p. 99)
}

É evidente que a construção poética dos versos mencionados anteriormente está atrelada ao fato de que o ser humano carrega consigo a identidade do local de origem, mesmo que esteja longe de sua cidade natal. Em resumo, o homem se perpetua pelo espaço, e cabe à memória registrar esse acontecimento, visto que a condição humana nunca é plena. Dessa forma, tornase primordial a completude do indivíduo, que está em outra parte, na exterioridade e no deslocamento do ser pelo espaço.

Em decorrência disso, Octavio Paz propõe o conceito de outridade, justamente, para designar a relação do homem com o outro, seja com o espaço que ocupa, seja com aquele que o torna semelhante. Na certeza desse encontro, o homem é capaz de redescobrir a sua parte na outra que desconhece, sem deixar de ser aquilo que realmente é: “[...] a outridade é antes de mais nada a percepção de que somos outros sem deixar de ser o que somos e que, sem deixar de estar onde estamos, nosso verdadeiro ser está em outra parte. Somos a outra parte" (PAZ, 2012, p. 107).

No que diz respeito, ainda, ao tema da memória, compreende-se que o poeta FG, a partir de suas próprias experiências, soube expressar, mediante a ação do eu lírico, os fatos de um período histórico marcante na vida da população brasileira. Da individualidade ao coletivo, o poeta de São Luís extraiu de sua massa existencial uma interpretação para os acontecimentos ocorridos no Brasil e no mundo, como a Segunda Guerra e a implantação do regime militar. Não utilizou a memória como instrumento de ataque, mas de aprofundamento sobre a história e os homens de sua época. Ademais, a relação do espaço com o homem e do homem com o tempo demonstra a potencialidade filosófica desse poema; pois, na sua simples aparência testemunhal, como propusera seu autor, habita o sentido poético em suas últimas instâncias. 
Finalmente, o Poema sujo não deixa de ser um texto de identidade, uma vez que a função da memória excede a simples recuperação de eventos ocorridos, mas possibilita o reencontro do homem consigo mesmo, assim como da história com seu próprio passado, no instante em que se tenta resgatar o contexto de uma época. Isso leva a crer que a "memória é um elemento essencial do que se costuma chamar identidade, individual ou colectiva, cuja busca é uma das actividades fundamentais dos indivíduos e das sociedades de hoje, na febre e na angústia" (LE GOFF, 1994, p. 46).

\section{Referências bibliográficas:}

ADORNO, T. Discurso sobre lírica e sociedade. In: LIMA, L. C. (Org.). Teoria da literatura em suas fontes. Rio de Janeiro: Francisco Alves, 1979.

BERGSON, H. Matéria e memória. Ensaio sobre a relação do corpo com o espírito. São Paulo: Martins Fontes, 1990.

GULLAR, F. Poema Sujo. 15ª ed., Rio de Janeiro: José Olympio, 2013.

LE GOFF, J. História e memória. Campinas: Editora da UNICAMP, 1994.

PAZ, O. Signos em rotação. Trad. Sebastião Uchoa Leite. São Paulo: Perspectiva, 2012.

RICOEUR, P. A memória, a história e o esquecimento. São Paulo: Editora da UNICAMP, 2007.

ROSSI, P. O passado, a memória, o esquecimento. São Paulo: Editora da UNESP, 2010. 